of the admirable organisers of the entire event, presented the results and anecdotes from her young-reader-response research into the reception of illustrated texts. Finally, Zoe Jaques presented a glimpse into the theory of "bookish, toyish, thingies" - beautiful, book-like artefacts which defy categorisation.

The final session was a plenary panel chaired by Philip Nel, in which Jessica Lim (the other indefatigable and commendable organiser!), Siddharth Pandey, Jason Scott-Warren, and Mary Anne Wolpert beautifully summed up all that was said during the Conference, taking both a historical and futuristic approach to the materiality of the children's book.

After the summing up and round of thank-yous and applause, the Conference was over, and a large number of participants gathered to dine on some very tasty Italian food.

I would like to wholeheartedly congratulate Jen Aggleton and Jessica Lim on organising this truly fantastic event. All the papers in each panel fitted perfectly, as if the presenters were in cahoots (we were not!), and there truly was no dull moment (or opportunity for a snooze occasioned by a boring presentation). I came back from this one-day symposium with more knowledge, inspiration, and motivation than from many longer congresses.

Karolina Rybicka

\title{
Sedma godišnja skupština Hrvatske udruge istraživača dječje književnosti
} Zadar, 12. svibnja 2017.

DOI: $10.21066 /$ carcl.libri.2017-06(01).0018

Sedmu po redu godišnju skupštinu HIDK-a ugostilo je Sveučilište u Zadru, u prostoru dvorane za poslijediplomske studije. Skupštinu je obilježilo zadovoljstvo rekapitulacijom zbivanja tijekom 2016., ali i entuzijazam zbog planova i aktivnosti HIDK-a u narednome razdoblju.

Prethodnu, 2016., godinu obilježila je Međunarodna znanstvena konferencija „Stoljeće Priča iz davnine Ivane Brlić-Mažuranić“. Konferencija se održala pod visokim pokroviteljstvom Predsjednice Republike Hrvatske od 12. do 15. listopada 2016. u Zagrebu, u prostorima suorganizatora, Hrvatske akademije znanosti i umjetnosti i Matice hrvatske. Svečano otvorenje Konferencije uveličali su predstavnici organizatora i obitelji Brlić i Mažuranić, a radni je dio započeo plenarnim izlaganjima Jennifer Miskec i Dubravke Zima. U tri radna dana Konferencija je okupila ukupno 153 izlagača, znanstvenika i stručnjaka iz Hrvatske i inozemstva, koji su svojim radovima dali važan doprinos istraživanju jednoga od rijetkih hrvatskih djela s tako bogatom međunarodnom recepcijom, koje je u sto godina svojega postojanja postalo nezaobilaznim mjestom hrvatske kulture. Posljednjega dana konferencije, 15. listopada 2016., organiziran je izlet u Ogulin, rodno mjesto autorice Ivane Brlić-Mažuranić.

$\mathrm{Na}$ uspjehu Konferencije, organizaciji programa, koordinaciji aktivnosti, izradi konferencijskih materijala, izgrađenoj mrežnoj infrastrukturi, opsežnoj korespondenciji te velikome trudu i uloženome vremenu čestitalo se Andrijani Kos-Lajtman, predsjednici Organizacijskoga odbora, Tihomiru Engleru, dopredsjedniku Organizacijskoga odbora i Nadi Kujundžić, tajnici Konferencije. Veliko priznanje dobili su i zbog izrade projektnih prijedloga za natječaje na temelju kojih su Konferenciju financijski poduprli Ministarstvo znanosti i obrazovanja, Ministarstvo kulture i Zaklada Hrvatske akademije znanosti i umjetnosti. 
Po završetku Konferencije pristupilo se pripremama za objavljivanje zbornika radova. Prikupljeni prilozi proći će dvostruki ,slijepi““ međunarodni recenzentski postupak, a s obzirom na opseg postoji mogućnost da će se zbornik tiskati u dvama tomovima. Zbornik će urediti Andrijana Kos-Lajtman, Nada Kujundžić i Sanja Lovrić Kralj.

Uspjeh u 2016. godini bilježi i časopis Libri \& Liberi, čija je glavna urednica Smiljana Narančić Kovač izrazila zadovoljstvo trenutnim statusom časopisa. Naime, u odnosu na početke, časopis sada uživa stabilnost u više pogleda. U financijskome pogledu, časopis prima redovitu podršku Ministarstva znanosti i obrazovanja već nekoliko godina, a u izvedbenome smislu časopis je oko sebe okupio cijelu mrežu suradnika koji tvore uhodani tim, što je u konačnici rezultiralo i ravnomjernijim rasporedom poslova. Časopis je postavio visoke standarde: svi su prilozi lektorirani i jezično usklađeni, a svakomu radu pridružuju se oznake UDK i DOI (digitalni identifikator objekta). Časopis je okupio i nekolicinu volontera, uglavnom studenata i studentica Učiteljskoga fakulteta, koji pomažu u korekturi te administrativnim poslovima i diseminaciji pojedinih brojeva. Na temelju postignutoga visokoga standarda i zahvaljujući njegovu zadržavanju, časopis Libri \& Liberi nagrađen je brojnim objektivnim priznanjima: ulaskom u neke od najvažnijih baza kao što su ERIH PLUS, Scopus, MLA, ESCI (Emerging Sources Citation Index, WoS), čime su se osigurale predispozicije i za priznanje hrvatske znanstvene zajednice i uvrštavanje časopisa među hrvatske časopise kategorije a1. Cilj je da se časopis u narednome razdoblju uključi i u bazu podataka Current Contents (skraćeno CC), što zahtijeva, kao i u slučaju drugih baza, redovito izlaženje.

Komunikacija s članovima HIDK-a i dalje se u najvećoj mjeri odvija elektroničkom poštom, međutim, naglasak se u budućnosti želi prebaciti na mrežnu stranicu <www.hidk.hr> na kojoj već rade urednica Marina Gabelica i nova članica HIDK-a Ana Željeznjak. Članovi se pozivaju da kolegicama javljaju novosti povezane s istraživanjem dječje književnosti i kulture iz različitih lokalnih sredina. Članovi se također podsjećaju da aktivnosti Udruge mogu pratiti i na HIDK-ovoj stranici na Facebooku.

Financijsko izvješće pokazalo je kako je godišnji prihod i rashod HIDK-a uravnotežen jer je većina velikih projekata HIDK-a poput tiska zbornika, organizacije Konferencije i objavljivanja časopisa barem djelomično financirana potporama nadležnih ministarstava (Ministarstva znanosti i obrazovanja te Ministarstva kulture), a dobivena se sredstva namjenski troše. Dobitak se očituje u uplaćenim članarinama, donacijama, pretplatama na časopis te prodaji zbornika „Šegrt Hlapić“ od čudnovatog do čudesnog. Rashodi koji se pokrivaju sredstvima Udruge uključuju računovodstvene usluge, redoviti trošak vođenja bankovnoga računa, godišnje članstvo u IRSCL-u te organizaciju Skupštine. Skupština je zaključila kako je Udruga tijekom sedam godina postojanja postigla željenu stabilnost poslovanja.

Planovi za naredno razdoblje rada HIDK-a obuhvaćaju objavljivanje šestoga godišta časopisa Libri \& Liberi, objavljivanje zbornika s konferencije „Stoljeće Priča iz davnine Ivane Brlić-Mažuranić“, poboljšanje komunikacije između članova te pripreme za sljedeću konferenciju. Naime, na Skupštini je dogovoreno da će HIDK 2019. godine ugostiti međunarodnu znanstvenu konferenciju The Child and the Book. Ove je godine konferencija održana u Valenciji (Španjolska), a iduće godine neće biti održana. Prijedlog Upravnoga odbora HIDK-a jest da se prijavimo za organizaciju Konferencije za 2019. godinu, prateći 
ritam od tri godine u organizaciji konferencija koji smo započeli Hlapićem 2013., a nastavili Pričama 2016.

Budući da su konferencije The Child and the Book tradicionalno (od prve konferencije 2004. godine) povezane s učiteljskim fakultetima, na Skupštini je usvojen prijedlog da HIDK tu konferenciju organizira u suorganizaciji s Odjelom za izobrazbu učitelja i odgojitelja Sveučilišta u Zadru i da se konferencija održi u Zadru. Kao mjesec održavanja konferencije odabran je svibanj jer su se sve dosadašnje konferencije The Child and the Book održavale u proljeće. Na Skupštini je formiran inicijalni Organizacijski odbor u sljedećem sastavu: Robert Bacalja, Ana Batinić, Katarina Ivon, Smiljana Narančić Kovač i Sanja Vrcić-Mataija. Za tajnicu Konferencije izabrana je Anja Matešić. I ostali članovi HIDK-a pozvani su da se uključe u organizaciju i daju svoj doprinos. Tema konferencije na Skupštini nije formulirana, ali je dogovoreno da naglasak, za razliku od dosadašnjih HIDKovih konferencija, više neće biti na prigodnim obljetnicama nego na dječjoj književnosti i problemima istraživanja dječje književnosti. Prvi se poziv planira za siječanj 2018.

Sanja Lovrić Kralj

Croatian Children's Books Awards in 2016

Hrvatske nagrade za dječju knjigu u 2016. godini

\section{Nagrada „Grigor Vitez" - The “Grigor Vitez” Award}

DOI: 10.21066/carcl.libri.2017-06(01).0019

Snježana Babić-Višnjić. 2015. Krugovi na vodi [Circles on the Water]. Zagreb: Alfa d. d. (Tekst za djecu / Category: text for children).

Rosie Kugli. 2015. Nisam ti rekla... [I Have not Told You...]. Zagreb: Hrvatsko društvo književnika za djecu i mlade. (Tekst za mladež / Category: text for young adults).

Ivana Guljašević. 2015. Nosorogov oglas Brune Kuman i Drveni neboder Ivane Guljašević [The Rhinceros's Advertisement by Bruno Kuman and The Wooden Skyscraper by Ivana Guljašević]. Zagreb: Igubuka d.o.o. (Za ilustracije za mlađu dob djece / Category: illustration for young children).

Dražen Jerabek. 2015. Tajna Dubravke Pađen-Farkaš. [A Secret by Dubravka PađenFarkaš]. Zagreb: Sipar d.o.o. (Za ilustracije za stariju dob djece / Category: illustration for older children).

Nagrada „Grigor Vitez“ najstarija je nagrada za dječju knjigu u Hrvatskoj. Dodjeljuje se od 1967. godine u Zagrebu. Osnivač je i pokrovitelj nagrade Savez društava „Naša djeca“"Hrvatske. Dodjeljuje se za najbolji tekst i ilustracije iz jednogodišnje produkcije dječje knjige u Hrvatskoj. Sastoji se od diplome, statue „Ptica“ akademske kiparice Ksenije Kantoci i novčanoga iznosa.

Grigor Vitez (1911-1966) was a Croatian children's poet, translator and editor of children's books. Founded in 1967 in Zagreb by the Union of Societies "Our Children", Croatia, the "Grigor Vitez" Award is the oldest children's book award in Croatia. The best literary text and illustrations selected from Croatia's annual production of children's books are awarded with a diploma, a bird-shaped statuette (the work of the sculptor Ksenija Kantoci), and prize money. 